Милан Јовановић

Универзитет у Нишу, Филозофски факултет
УДК 378.147:16]:316.64-057.875

Оригинални научни рад

Примљено: 22. 08. 2020.

https://doi.org/10.46630/gflz.3.2021.01

\title{
УТИЦАЈ КУРСЕВА ИЗ ЛОГИКЕ НА СТАВОВЕ СТУДЕНАТА
}

\begin{abstract}
Резиме: У овом раду сводимо и анализирамо резултате пројекта који је био посвећен истраживању питања - да ли курсеви из логике утичу на студентска уверења поводом логике, и ако да, на који начин. Наше начелно очекивање било је да логички курсеви значајно утичу на релевантне студентске ставове, али да тај утицај варира с обзиром на усмерење конкретних курсева. Метод нашег емпиријског истраживања базирао се на испитивању (помоћу тестова) студентских ставова поводом одређених тврдњи. Тестирање смо спровели у два круга, пре и након што су студенти одслушали дате курсеве, да бисмо потом међусобно упоредили те тестове. Резултати, иако различити од хипотезе до хипотезе, ипак генерално поткрепљују закључак да курсеви из логике утичу на релевантне ставове студента, и то на начин који је у сагласности са теоријским усмерењем самих силабуса датих курсева.
\end{abstract}

Кључне речи: логика, аргументација, методологија, настава, силабус.

\section{0. Увод}

Овај рад настао је као резултат пројекта „Утицај курсева из филозофије на ставове студената“, који је департман за филозофију Филозофског факултета Универзитета у Нишу спроводио у академској 2018/2019. години. Сврха пројекта је била да се (емпиријски) испита у којој мери курсеви филозофије утичу на ставове студената. Главна хипотеза пројекта је да тај утицај постоји и да је значајан.

У овом раду бавићемо се само једним делом резултата тог истраживања. Наиме, предмет нашег излагања биће утицај логичких курсева на ставове студената. У првом делу рада кратко ћемо представити логичке курсеве на нашем студијском програму. Други део рада тицаће се методологије истраживања на пројекту и хипотеза које смо тестирали. Трећи део рада је главни, у њему ће бити речи о резултатима истраживања. Четврти део рада биће посвећен закључцима изведеним из овог истраживања.

\section{1. Садржај логичких курсева}

Према студијском програму акредитованом 2014. године, на основним академским студијама филозофије налазе се четири једносеместрална логичка 
курса, и сва четири су обавезна. На првој години студенти слушају увод у логику 1 и увод у логику 2, док у другој имају логику 1 и логику 2. Курсеви имају идентичан број часова и носе по 7 (уводи у логику) односно по 6 (логике) ЕСП бодова.

Увод у логику 1 и 2 су, разумљиво, уводни курсеви, осмишљени тако да их могу пратити и студенти који као ученици нису имали никаквих додира са логиком. ${ }^{1}$ Предмет логике је на том курсу одређен врло једноставно и тако као да се најдиректније тиче природног (обичног) језика, аргументације и критичког мишљења. Логика се, наиме, у препорученој литератури за испит на том курсу одређује као филозофска дисциплина која се бави правилима и облицима ваљьаног мишььења (Петровић 1997), односно као дисциплина која се бави проценом вредности сведочанства (Коен и Нејгел 2004), или као организовано тело науке које процењује закључивање (Харли 2012). Поред овог одређења логике, главне теме увода у логику 1 су: термин и појам, конотација и денотација термина, дефиниција, деоба и класификација, исказ и структура исказа, односи међу исказима и логички квадрат. Операције над простим исказима, валидност и истинитост. Логика се на овом курсу ради највећим делом неформално и тематски се преклапа са теоријом аргументације у многим деловима. Управо у том аспекту би требало да је студентима и корисна - јер им говори о стварима које свакодневну сусрећу, објашњава им како функционишу дефиниције, поделе, тврдње и њихове негације...

Увод у логику 2 је суштински сконцентрисан на традиционалну аристотеловску логику, тј. силогистику. На том курсу се и даље подразумева одређење логике из увода у логику 1 , али се оно сада посматра као повод за изградњу теорије о валидности закључивања. То се, у централном делу курса, чини пратећи Аристотелову теорију силогизма. Поред силогистичких тема, овај курс садржи и неколико тема из исказне логике - мада такође представљене на традиционалан начин (кроз анализу посредних закључивања са сложеним премисама) - као и проблематизацију егзистенцијалног значења универзалних исказа. Овај курс из другог семестра је за нијансу формалнији од оног који му претходи. ${ }^{2}$

Курсеви из логике 1 и 2 су значајно комплекснији од описаних курсева са прве године. У њима се логика учи потпуно формално, са фокусом на вештачке језике. Такође, рачуна се са једним прецизнијим одређењем логике. Она се ту одређује као наука о дедукцијама (Дошен 2013), односно математичка дисциплина, део дискретне математике, која се бави објективном релащијом логичке импликације (Коен и Нејгел 2004). Поред стандардних тема из исказне логике (у оквиру логике 1) и предикатске логике (у оквиру логике 2), ови курсеви садрже и неке метатеоријске теме: базе везника, теорема дедукције,

\footnotetext{
${ }^{1}$ Нажалост, осим гимназија (где се логика учи у трећем разреду) наше друге средње школе немају ни као обавезни ни као изборни предмет логику. 3бог тога, случај да се студент први пут сусреће са логиком на факултету (било да студира филозофију, математику или информатику) врло је чест.

${ }^{2}$ Током њега се студенти навикавају да користе симболичке записе, као и да користе методу истинитосних таблица.
} 
докази потпуности и непротивречности. На тим курсевима проблематизује се и примена логике на аргументацију, ограничења те примене, проблеми односа природног и вештачког језика и тако да даље. Главне теме курса из логике 1 су: семантика и синтакса језика исказне логике, методе одлучивања о формалним својствима и релацијама исказа и скупова исказа помоћу истинитосних таблица и дрвета, основе природне дедукције и докази у њој, превођење из обичног језика у исказни рачун и обрнуто, Канторови појмови пребројивости и кардиналности, математичка и тотална индукција.

Главне теме курса из логике 2 су: семантика и синтакса језика предикатског рачуна, релацијско-операцијске структуре, превођење из обичног језика у предикатски рачун и обрнуто, докази у природној дедукцији, аксиоматски системи и докази у њима, метатеореме предикатског рачуна.

Литература која се користи за логичке курсеве у другој години је: Дошен 2013, Коен и Нејгел 2004, Борисављевић 2009, Прешић 1972; а као помоћна књига са вежбањима и решењима: Bergmann et al. 2008.

Нема дилеме да логика 1 и 2 нуде појам логике који је комплекснији и са којим су доведене у питање подразумеване везе између обичног језика и свакодневног резоновања са самим предметом логике и његовом формалном природом. Било би очекивано да студенту који је слушао и положио логику 1 и 2 поље аргументације изгледа као једна примена логике (обогаћена и другим дисциплинама, као што су: реторика, психологија, филозофија језика, социологија), а не као нешто у чему се логика исцрпљује.

\section{2. Хипотезе и методологија истраживања}

Основна хипотеза овог дела нашег истраживања је да курсеви из логике утичу на промену релевантних ставова наших студената. Идеја водиља, стога, била је да истражујемо промене у релевантним студентским ставовима пре и након похађања датих курсева. Због тога, анкетирани су студенти филозофије, и то у два циклуса: пре и након слушања логичких курсева. У обе те прилике дат им је идентичан тест којим су испитивани њихови ставови поводом различитих тврдњи које су директније или мање директно повезане са логиком. Од студената је тражено да заокруже број на скали од 1 до 5, зависно од степена слагања са датом тврдњом, где је „,““ негативни крај скале и стоји за ,у потпуности се не слажем“, а „5“ позитивни крај и стоји за „у потпуности се слажем“.

Будући да су нас занимали њихови нерефлектовани ставови, тј. како се то често у филозофији каже, њихове интуиције поводом различитих питања, студентима смо пре тестирања давали инструкције да наравно нема тачних и нетачних одговора, као и да се од њих не очекује да дубоко тематски промисле свако од питања пре одговарања, већ да заокружују према свом интимном осећају да ли се и у којој мери слажу са датим тврдњама. Тврдње, пак, поводом којих су били анкетирани нису међу тврдњама које се помињу на самим филозофским курсевима. У том, смислу наша хипотеза је истраживачки храб- 
рија (или барем мање неконтроверзна) и предвиђа да ће се $u$ mе (такве) њихове интуиције мењати након филозофских и логичких курсева, а не само њихова теоријска уверења (што је свакако мање контроверзно очекивање).

Тестови су били анонимни али шифрирани, тако да се могу упоређивати тестови истог студента пре и након његовог слушања одређених курсева. Анализа промене је рађена тако што је од оцене (слагања са датом тврдњом) из другог круга тестирања одузимана оцена из првог круга тестирања. Због специфичности термина тестирања, као и због саме чињенице да на студијском програму за филозофију нема пуно студената, узорак на којем је спроведен овај део истраживања (који се тицао утицаја логичких курсева) састојао се од само 14 студената - 6 студената прве године и 8 студената друге године.

Тврдње (ставови) на којима смо посматрали утицај курсева из логике су следеће: ${ }^{3}$

3. Знање из области логике није применљиво у свакодневном животу.

9. Проучавање логике подстиче критичко мишљење.

15. Разумевање структуре и веза између информација олакшавају учење и спремање испита.

21. Мимо поштовања логичких процедура може се неизоставно доћи до истинитих закључака.

28. Сматрам да је познавање логике потребно за правилно разумевање јавних и политичких дебата.

34. Учење логике подстиче креативност у мишљењу.

41. Оно што се сматра тачним мишљењем није се мењало кроз историју.

47. Методички је исправно и тиме и оправдано до филозофских и других ставова долазити и помоћу непосредног искуства и интуиција, а не искључиво праћењем логичких процедура.

Тврдње су врло разноврсне у једном методолошки релевантном смислу. Наиме, код неких од њих би - имајући у виду садржај силабуса датих логичких предмета, а у складу са начелном хипотезом истраживања - било рационално очекивати да се након курса повиси оцена која изражава степен слагања студента са датом тврдњом. Код неких других би пак очекивана промена била смањење оцене. Другим речима, очекивана промена у оцени (p) изражена разликом $\boldsymbol{p}=\boldsymbol{o}_{2}-\boldsymbol{o}_{1}$ (где $o_{1}$ означава степен слагања пре, а $o_{2}$ након слушања курса), поводом неких ставова ће бити позитивна а поводом неких негативна вредност. С обзиром на ово, могуће је формулисати специфичне хипотезе за свако од питања - у смислу прецизније формулације очекивања поводом промене студентског става о том питању, у зависности од конкретног питања и конкретног слушаног курса између два циклуса тестирања.

Зависност тих очекивања од конкретног курса јако је важна, будући да се курсеви из логике 1 и 2, као што је показано, заиста значајно разликују од

\footnotetext{
3 Лево од датих тврдњи налазе се њихови редни бројеви у самом тесту (тест је наравно садржао и друге тврдње, релевантне за друге области истраживања). Касније ћемо користити те редне бројеве да лакше упућујемо на одређена питања, зато их овде излиставамо уз тврдње.
} 
курсева из увода у логику. Због тога су наше специфичније хипотезе поводом неког одређеног питања различите код студената прве године од оне за студенте друге године. У наставку ћемо излистати те хипотезе, и кратко их теоријски оправдати, пре него што се у наредном поглављу окренемо резултатима.

Наше очекивање поводом 3. питања из теста је да ће студенти прве године променити свој став након курса тако што ће нижом оценом изразити своје слагање са датом тврдњом. Курсеви из увода у логику заиста наглашавају применљивост логике у свакодневним контекстима, те би ово био очекиван утицај тог курса - да студентске интуиције поводом применљивости логике буду промењене на такав начин.

С друге стране, курсеви из логике фокусирани су на један технички дорађенији појам логике, формалнији и стручнији. На том курсу се не говори пуно о аргументацији нити о резоновању. Посебно имајући у виду контраст који студенти сусрећу на том преласку из прве у другу годину, очекивано би било да њихова процена применљивости логике благо пада, односно да оцена слагања са тврдњом о неприменљивости ${ }^{4}$ буде у благом расту.

Дакле, одговарајуће хипотезе поводом утицаја курсева на став са редним бројем 3 у тесту биле би ове:

$\mathbf{H}_{\text {зи }}$ : Студенти прве године оцењиваће тврдњу под бројем $\mathbf{3}$ нижим оценама у другом него у првом кругу тестирања.

$\mathbf{H}_{31}$ : Студенти друге године оцењиваће тврдњу под бројем $\mathbf{3}$ вишим оценама у другом него у првом кругу тестирања. ${ }^{5}$

Ситуација поводом питања под редним бројем 9, 15 и 28 врло је слична овој управо назначеној. Важна разлика је, ипак, у томе што су те тврдње усмерене афирмативно. Због тога, адекватне хипотезе у вези са њим изгледају овако:

$\mathbf{H}_{9,15,28 u}$ : Студенти прве године оцењиваће тврдње бр. 9, 15 и 28 вишим оценама у другом него у првом кругу тестирања.

$\mathbf{H}_{9,15,281}$ : Студенти друге године оцењиваће тврдње бр. 9, 15 и 28 нижим оценама у другом него у првом кругу тестирања.

Тврдње под бројем 21 и 47 су комплексније и проблематичније, макар у том смислу што су поред извесне везе са курсевима из логике, оне ипак повезане и са методолошким поукама које студенти и прве и друге године могу добити бавећи се историјом филозофије, а студенти друге и на курсевима из

\footnotetext{
${ }^{4}$ Тврдња је дата у негативном облику, тако да су студенти заправо оцењивали у којој мери се слажу са тим да логика није применљива у свакодневном животу.

${ }^{5}$ Хипотезе је могуће формулисати и у појмовима позитивне и негативне вредности промене, подразумевајући да је она (вредност промене) дата као $o_{2}-o_{1}$. На пример, $\mathrm{H}_{3 \mathrm{u}}$ и $\mathrm{H}_{31}$ би се на тај начин могле преформулисати у: $\mathrm{H}_{3 \mathbf{u}^{*}}$ Код студената прве године вредност промене код тврдње 3 . биће негативна;

и $\mathrm{H}_{31 *}$ Код студената друге године вредност промене код тврдње 3. биће позитивна.
} 
етике, естетике, па и психологије и социологије. ${ }^{6}$ Свест о овим релевантним околностима (од којих су неке чак и варијабилне) 7 чини предвиђање далеко тежим. Ипак, наш став је да би питање 21, пре свега због нагласка на речи „неизоставно“ морало бити одговорено нижим оценама након слушања курсева из логике. Свест о неопходности поштовања логичких процедура зарад нужно истинитих закључака требало би да буде довољна да студенти након курсева буду мање склони томе да се сложе да се и без тога може доћи до таквих закључака и мимо поменутих процедура.

Питање 47 фокус ипак ставља на методологију и лако се може догодити да је „погођено“ и познатом критиком силогистике - да она ипак не може представљати organon за научно истраживање, будући да се оно у основи не може свести на дедуктивно. Исто тако, још уже и прецизније одређење логике које имамо у другој години, наглашава њену аналитичност те јасно ставља до знања да се за напредак знања морају упошљавати друге методе од оних о којима је на курсевима из логике реч. Због свега тога, очекивано је да слагање студената са том тврдњом - да је методички исправно и оправдано до филозофских и других ставова долазити и помоћу непосредног искуства и интуиција, а не искључиво праћењем логичких процедура - чак и расте, тј. да је у другом кругу тестирања у обе године та оцена виша, те да промена буде позитивна вредност. Релевантне хипотезе би дакле изгледале овако:

$\mathbf{H}_{21}$ : Студенти и прве и друге године оцењиваће нижим оценама тврдњу бр. 21. у другом кругу тестирања.

$\mathbf{H}_{47}$ : Студенти и прве и друге године оцењиваће вишим оценама тврдњу бр. 47. у другом кругу тестирања.

Тврдња под бројем 34 је једним делом нејасна, јер се у њој помиње „креативност“ коју је заиста могуће схватити на више начина. У једном смислу те речи, логика (и она која се ради на уводу и она у другој години, на самим курсевима из логике) заиста је далеко од креативности. Али, када погледамо с друге стране, увод у логику на неки начин обогаћује нашу способност да проблемима приђемо с више страна, да променимо дирекцију приликом решавања неких проблема и томе слично. Све то би неко лако могао рачунати у креативност, будући да креативност јесте део тог процеса дивергентног мишљења.

Курсеви из логике 1 и 2 су другачији и тешко да се могу повезати и са овом врстом креативности. Ипак, бављење доказивањем - у природној дедукцији, али и у математичкој индукцији - може на неки (не сасвим непроблематичан начин) бити повезано са креативношћу. Свеједно, наша је претпоставка да ће

\footnotetext{
${ }^{6}$ Различити курсеви са департмана за психологију и социологију су понуђени као изборни за први и други семестар друге године.

7 Таква околност је, на пример, и то који од изборних предмета је узет на другој години, али и евентуални одабир тема семинарских радова из историје филозофије. Замисливо је да неки студент промени своје ставове о методологији сазнања на основу дубље и интимније упознатости са неким грчким или средњевековним филозофом, као и захваљујући темељнијем бављењу неком емпиријском хуманистичком науком.
} 
се ова нејасноћа на групи одразити тако да ће код студената прве године након слушања курса слагање са тврдњом да учење логике подстиче креативност у мишљењу - расти, те да ће $\boldsymbol{p}$ (дефинисано као раније) бити позитивно и значајно. С друге стране, код студената друге године очекујемо суптилнију промену у истом смеру, дакле очекујемо да $\boldsymbol{p}$ буде позитивно али мање изражено.

$\mathbf{H}_{34}$ : Студенти прве и друге године оцењиваће тврдњу бр. 34 вишим оценама у другом него у првом кругу тестирања, с тим што се очекује да вредност промене буде већа код студената прве године.

На крају, имамо и тврдњу 41 чија је веза са логиком, опет, проблематична, иако постоји. Рационално је очекивати да ће у њој студенти препознати питање о разлици између традиционалне и савремене логике. Та тема тек је начета у првој години, иако јесте назначена. С друге стране, у другој години, на курсевима из логике 1 и 2 инсистира се на томе да логика мора имати другачије основе од оних које нуде силогистика. Због тога, хипотеза поводом тврдње 41 изгледа овако:

$\mathbf{H}_{41}$ : Студенти прве и друге године оцењиваће тврдњу бр. 41 нижим оценама у другом него у првом кругу тестирања, с тим што се очекује да вредност промене буде већа код студената друге године.

Овим је завршено излагање методологије нашег истраживања и представљање наших очекивања. Пре излагања конкретних резултата, требало би још једном напоменути да број испитаника у истраживању обавезује на то да се ови резултати свакако узму уз извесну резерву. Такође, потенцијално ометајући фактор овог истраживања је и то што извесни студенти очигледно имају одлично памћење и вероватно уз то извесну потребу за доследношћу. Те две особине могу лако смањити вредност промене чак и онде где извесна промена у ставовима заиста постоји, али се напросто не показује. То су све методолошка и техничка ограничења нашег истраживања.

\section{3. Резултати истраживања}

Резултате ћемо презентовати прво у двема табелама које показују готово све важне податке, па ћемо касније проћи кроз сваку од хипотеза. Прва табела даје податке за студенте прве године који су слушали курсеве из увода у логику 1 и 2. 


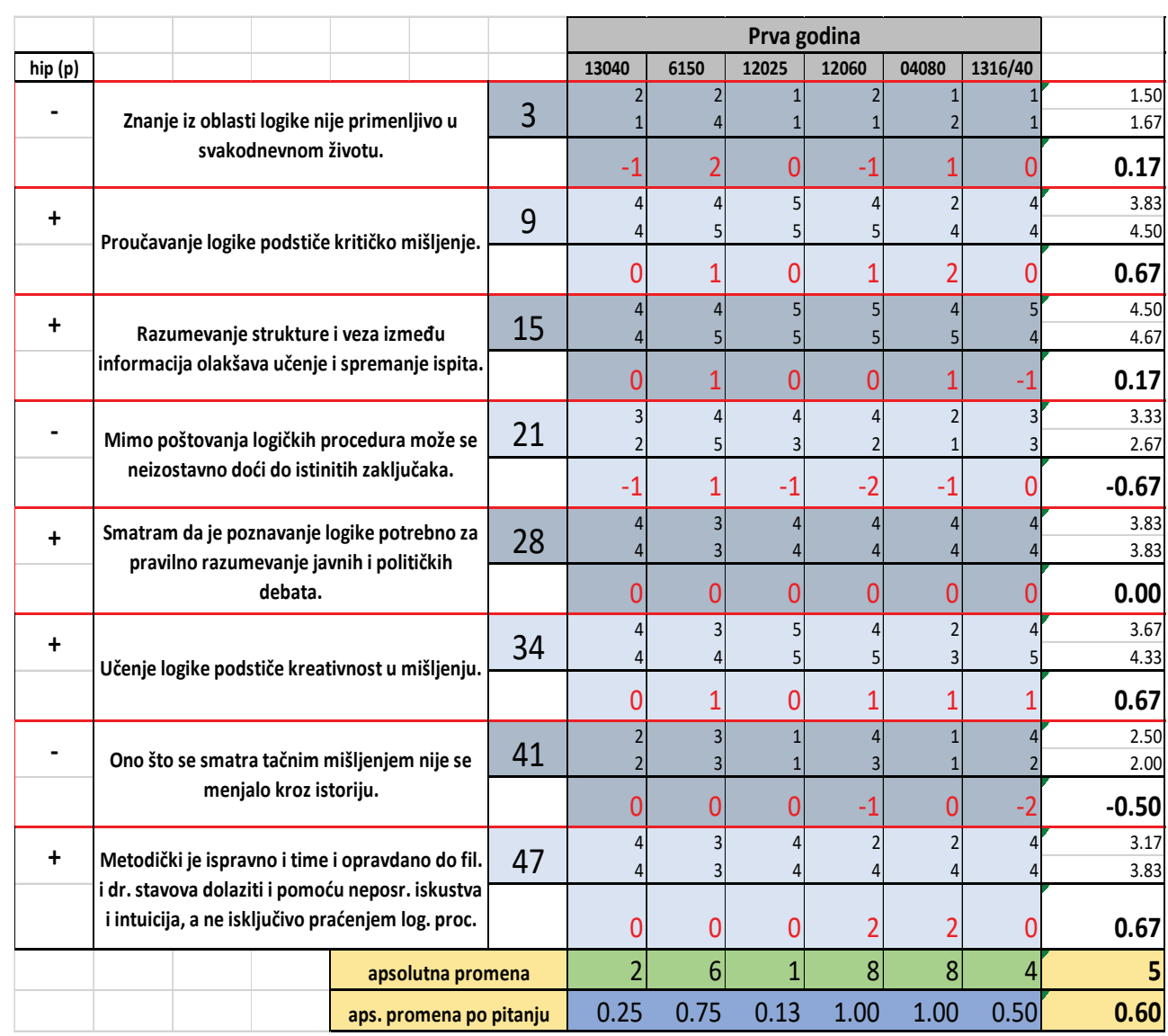

Табела 1: Резултати истраживања на испитаницима са прве године студија.

У колони уз леви угао табеле, знаци „,+“" и ,-““ односе се на хипотезе (које су раније излистане) и на то да ли је према њима очекивано да $\boldsymbol{p}$ буде позитивно или негативно. Поред су, надесно, конкретне тврдње које посматрамо и њихови редни бројеви у тесту. У остатку табеле, у колонама испод шифри, дате су оцене које су студенти давали, и то прво она у првом кругу тестирања, па потом (тј. испод) она у другом кругу. Велики број који следи изражава вредност разлике $($ тј. $\boldsymbol{p})$. За свако од тих поља се у хоризонталном реду налазе просечне вредности за све тестиране студенте. Тако је, на пример, просечна вредност промене за став студената у вези са тврдњом под редним бројем 3 у тесту $\boldsymbol{p}=\boldsymbol{0 . 1 7}$, док је за тврдњу под бројем 21 та вредност $\boldsymbol{p}=\mathbf{- 0 . 6 7 .}$

Друга табела садржи податке о анкетирању студената друге године који су слушали курсеве из логике 1 и 2. Треба такође имати у виду да они приликом првог тестирања нису били у некој нултој позицији поводом својих уверења, будући да су они до тада већ слушали (а многи и положили) увод у логику 1 и 2. 


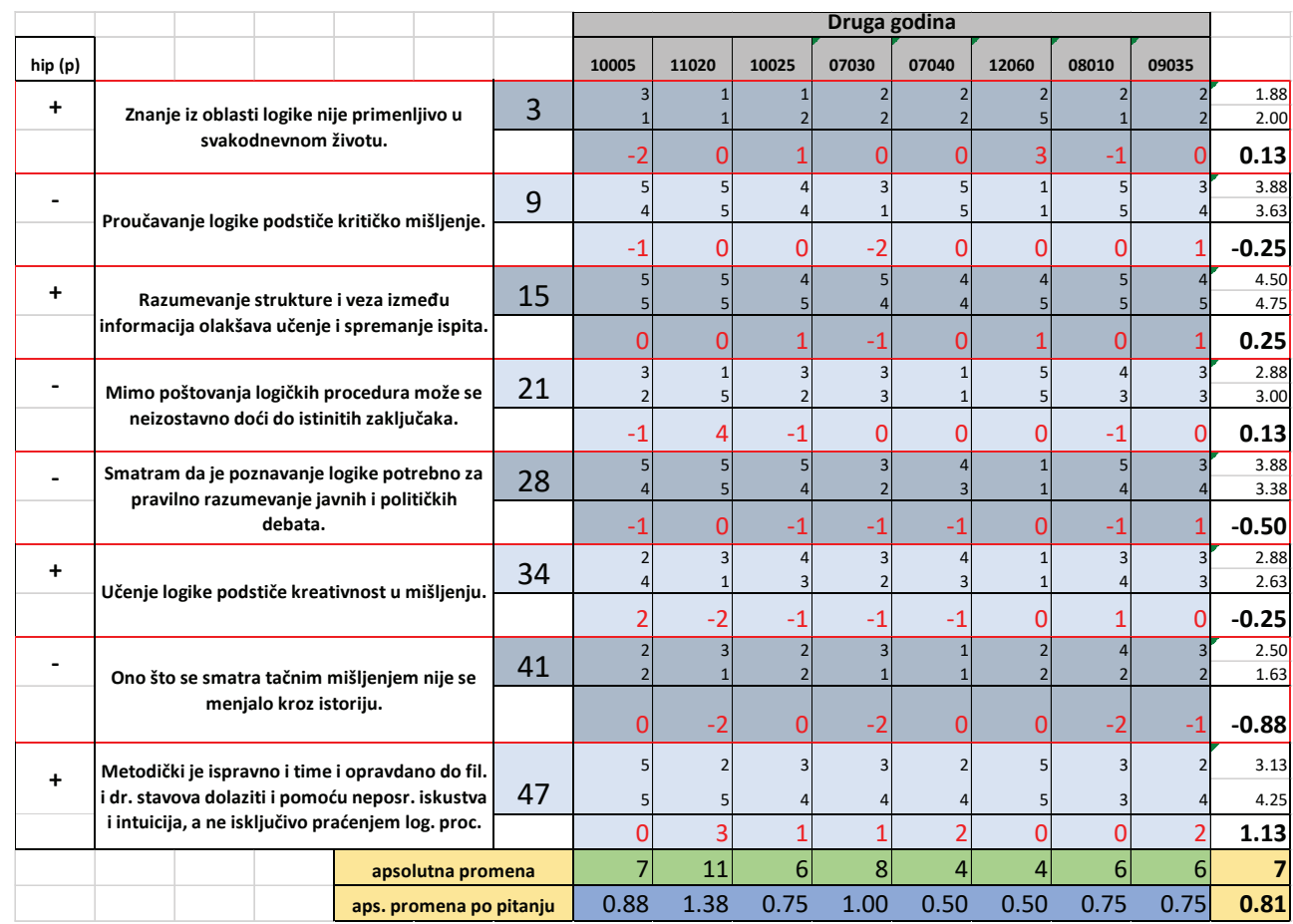

Табела 2: Резултати истраживања на испитанищима са прве године студија

Табела је структурно идентична оној претходној, те су једине разлике у назначеним хипотезама (помоћу плусева и минусева, лево, као и малочас), као и конкретним унетим и израчунатим вредностима.

Окренимо се хипотезама. Повод ставова студената у вези са тврдњом 3, имали смо две различите хипотезе (дате горе: $\mathbf{H}_{3 \mathbf{u}}$ и $\mathbf{H}_{31}$ ). Очекивали смо да ће $\boldsymbol{p}$ бити негативно код студената прве године, а позитивно код студената друге. Резултати у значајној мери одударају од очекивања. Код испитаника са прве године је $\boldsymbol{p}=\boldsymbol{0 . 1 7}$, а код испитаника из друге године $\boldsymbol{p}=\boldsymbol{0 . 1 3}$. Вредности су, дакле, веома међусобно блиске, обе су позитивне и обе врло ниске. Дакле, промене скоро да и нема у оба случаја. ${ }^{8}$

Потенцијално објашњење, макар код студената прве године, могло би се наћи у томе што су већ њихове иницијалне оцене биле јако ниске (просечна оцена је била 1.5), тако да би и у идеалном случају, да су сви у другом кругу јединицом одредили свој степен слагања са тврдњом, разлика била -0.5. И заиста, већина њих заокружила је јединицу, осим двоје студената који су заокружили 2 и $4 .{ }^{9}$

\footnotetext{
${ }^{8}$ Интуитивније речено, студенати прве године су, према овим резултатима, променили своју процену слагања са датом тврдњом (након курсева из увода у логику) у просеку за шестину једне оцене.

${ }^{9}$ Могуће је да је и присуство негације у питању збунило колегу са прве године па је чак и грешком након 1 у првом кругу тестирања и одслушаних курсева из увода у логику заокружио 4 - већином се слажем. Нешто врло слично је можда случај и код студената друге године, где је само један
} 
Погледајмо сада две хипотезе поводом чак три тврдње и студенских ставова о њима. Наиме, у $\mathbf{H}_{9,15,28 u}$ и $\mathbf{H}_{9,15,281}$ имали смо обрнута очекивања него изнад - да код студената прве године $\boldsymbol{p}$ буде позитивно, а код колега са друге негативно. И заиста, вредности промене за студенте прве године поводом свих ових ставова су позитивни. Ипак, апсолутну потврду ова прва хипотеза $\left(\mathbf{H}_{\mathbf{9}, 15,28 u}\right)$ има једино поводом тврдње под редним бројем 9 , где је $\boldsymbol{p}=\mathbf{0 . 6 7}$, што практично значи да су ставови наших бруцоша мењали у смеру очекиваног утицаја курса и то за две трећине оцене у просеку. Поводом друга два наведена става, значајнијих промена ипак нема: код тврдње 15 студенти прве године променили су своју оцену слагања у просеку за само $\mathbf{0 . 1 7}$, док су код тврдње 28 оцене остале идентичне $(\boldsymbol{p}=\mathbf{0 . 0 0}) .^{10}$

Што се тиче студената друге године, наша предвиђања остварила су се поводом ставова у вези са тврдњом 28. У контрасту са њиховим ставом у првом кругу тестирања - где су у просеку изражавали слагање у великој мери са тврдњом да је познавање логике потребно за разумевање јавних дебата (просечном оценом 3.88) - студенти друге године показали су значајно суздржанији став приликом тестирања на крају семестра, након курсева из логике 1 и 2. Вредност промене код те тврдње је $\boldsymbol{p}=\mathbf{- 0 . 5}$. Постоји суптилан пад и у степену слагања са тврдњом број $9(\boldsymbol{p}=\mathbf{- 0 . 2 5})$. Разлог за обе ове промене сугерисан је током излагања садржаја курсева из логике 1 и 2 , као и током формулисања хипотеза. Ваља приметити и да су резултати, уз раније назначене ограде, ипак фалсификовали хипотезу поводом ставова студената о тврдњи 15 , где је вредност промене позитивна $(\boldsymbol{p}=\boldsymbol{0 . 2 5})$.

Хипотезе $\mathbf{H}_{21}$ и $\mathbf{H}_{47}$ не хипостазирају различита очекивања поводом студената прве и друге године. Оне се могу преформулисати овако:

$\mathbf{H}_{21}$ : Вредност промене у степену слагања поводом тврдње бр. 21, и код студената и прве и друге године биће негативна.

$\mathbf{H}_{47}$ : Вредност промене у степену слагања поводом тврдње бр. 47, и код студената и прве и друге године биће позитивна.

Резултати су следећи. Вредност промене за тврдњу 21, за прву годину, је $\boldsymbol{p}=\mathbf{- 0 . 6 7}$, а за другу $\boldsymbol{p}=\boldsymbol{0 . 1 3}$. Аспект хипотезе који се тиче прве године је потврђен, промена је очекивано негативна и значајна. Део хипотезе који се односи на студенте друге године, међутим, није у складу са резултатима.

Што се тиче ставова студената поводом тврдње 47, вредности су следеће: за прву годину: $\boldsymbol{p}=\boldsymbol{0 . 6 7}$, а за другу: $\boldsymbol{p}=\mathbf{1 . 1 3}$. Ови резултати у потпуности потврђују хипотезу $\mathbf{H}_{47}$. Притом, вредност промене коју имамо у овом случају највиши су који су забележени када су у питању ставови за које су курсеви из логике релевантни. У једноставним терминима, студенти друге године су

студент заокружио 5 приликом другог тестирања. Иако је на том месту та промена у складу са очекивањима, драстичност промене (на првом тесту одговор је био „2“) указује на то да по среди може бити и грешка, а можда и неискреност приликом одговарања.

${ }^{10}$ И то не само у просеку, него су заиста сви студенти прве године задржали идентичне одговоре у оба теста - што је својеврсни куриозитет (погледајте табелу 1). 
у просеку за више од једне целе оцене боље оцењивали слагање са датом тврдњом након курса (него што су то чинили пре).

Надаље, имамо хипотезу поводом ставова студената о значају логике за креативност у мишљењу $\left(\mathbf{H}_{34}\right)$. Њу можемо операционализовати овако:

$\mathbf{H}_{34}$ : Вредност промене за студенте и прве и друге године поводом тврдње бр.

34 биће позитивна, с тим што се очекује да она буде већа код студената прве године.

Резултати, опет, само делимично потврђују очекивања. Наиме, за прву годину је $\boldsymbol{p}=\boldsymbol{0 . 6 7}$, док за другу годину вредност не само да је мања, него је чак и негативна $(\boldsymbol{p}=\mathbf{- 0 . 2 5})$ - што противречи очекивањима.

На крају, имамо и хипотезу $\mathbf{H}_{41}$, према којој би вредност $\boldsymbol{p}$ морала да буде негативна за испитанике обе године, уз очекивање да ће та вредност бити израженија код студената друге године.

Резултати овде у потпуности потврђују хипотезу $\mathbf{H}_{41}$. Вредности су: за студенте прве године $\boldsymbol{p}=\mathbf{- 0 . 5}$, а за студенте друге године $\boldsymbol{p}=\mathbf{- 0 . 8 8}$. Опет, вредности су релативно високе, обе негативне и друга је значајно већа од прве - као што је и очекивано.

\section{4. Закључци поводом истраживања}

У истраживању смо дошли до занимљивих резултата. У њима се показало да су неке наше прелиминарне и теоријске претпоставке или нетачне или такве да се морају истраживати на другачији начин. Друге међу њима истраживање је пак доказало.

Да сумирамо. Имали смо 8 тврдњи и две групе испитаника на којима смо истраживали ставове поводом тих тврдњи. У релативно економичном духу, а у складу са начелном хипотезом самог пројекта - да курсеви из филозофије утичу значајно на ставове наших студената - оформили смо 8 специфичнијих хипотеза. У табели испод дат је преглед потврђености сваке од хипотеза.

\section{Хипотеза Потврђена у потпуности}

Делимично

Није потврђена

потврђена

\begin{tabular}{|c|c|c|c|}
\hline$H_{3 u}$ & & & $x$ \\
\hline $\boldsymbol{H}_{31}$ & & & $x$ \\
\hline$H_{9,15,28 u}$ & & 凶/ $\square$ & \\
\hline $\boldsymbol{H}_{9,15,281}$ & & 凶/ $\square$ & \\
\hline$H_{21}$ & & 凶/ $\square$ & \\
\hline$H_{47}$ & $\checkmark$ & & \\
\hline$H_{34}$ & $\checkmark$ & & \\
\hline$H_{41}$ & $\checkmark$ & & \\
\hline
\end{tabular}

Табела 3: Потврђеност истраживачких хипотеза 
Извесне резерве поводом датих резултата поменуте су већ раније у раду. Назначено је да мали број испитаника заиста представља озбиљан проблем за овај тип истраживања. Исто тако, треба узети у обзир и ефекат памћења, који приликом понављања истих тестова лако може додатно умањити промене видљиве у тесту. Треба, такође, додати да ни сами термини тестирања нису били увек идеални са становишта методолошке прецизности самог пројекта.

Уз све ове техничке и методолошке проблеме, јасно је на основу резултата да ставови студената варирају и то ипак доминантно у смеру који би се могао очекивати с обзиром на курсеве који слушају. Овај резултат у складу је са начелном хипотезом пројекта - да курсеви праве разлику када су у питању ставови студената филозофије, па чак и када су у питању они нерефлектовани ставови (интуиције) о којима на самим курсевима није било речи.

Ови резултати, с једне стране, охрабрују јер говоре у прилог сврсисходности образовања - прецизније, ефективности факултетских курсева. Ставове је природно и пожељно мењати под утицајем едукације, боље информисаности или бољег разумевања. Ово, по свему судећи вреди и за нерефлектоване ставове, иако се они засигурно теже мењају од оних првих. Ипак, факултетски курсеви, очигледно, могу утицати и на уверења која се налазе у доживљајној равни.

С друге стране, ови резултати и обавезују све нас који учествујемо у процесу образовања као професори или сарадници, будући да наглашавају да постоји извесна повезаност између курсева које држимо и ставова студената. То свакако имплицира и извесну, додатну, одговорност и са наше стране.

У уско истраживачком смислу, прави резултати овог истраживања биће они који прате читаву једну генерацију, од тестирања пре свих курсева, до оног тестирања на крају студија, након свих одслушаних и положених испита. То ће, у једном смислу, умањити негативан ефекат проблема са уском групом испитаника, будући да ћемо макар вертикално имати шири спектар информација, те самим тим и веће поуздање у резултате које добијамо.

\section{Литература}

Борисављевић, М. (2009) Увод у логику, I део, Београд: Саобраћајни факултет.

Дошен, К. (2013) Основна логика, манускрипт доступан на:

http://www.mi.sanu.ac.rs/ kosta/Osnovna\%20logika.pdf

Коен, М. и Нејгел, Е. (2004) Увод у логику и научни метод, Београд, Јасен.

Петровић, Г. (1997) Логика, Београд, Завод за издаве уџбеника.

Прешић, С. (1972) Елементи математичке логике, Београд: Завод за издавање уџбеника социјалистичке републике Србије.

Харли, П. (2012) Кратак увод у логику, (превод издања: Hurley, J. (2008), са енглеског превели: М. Радић, М. Богдановски) Београд: Завод за уџбенике.

Bergmann, M, Moor, J. and Nelson, J. (2008) The Logic Book, 5th edition, New York: McGraw Hill. 
Hurley, J. (2008) A Concise Introduction to Logic, $3^{\text {rd }}$ ed., Belmont: Wadsworth.

Силабуси за логичке предмета су доступни на:

- $\quad$ За увод у логику 1 и 2:

https://drive.google.com/drive/u/0/folders/1IbMewUEGCAB8qZM0NsGwzOeYKWaFa iZ3

- $\quad$ За логику 1 и 2:

https://rive.google.com/drive/u/0/folders/1QozeFyeTBaOixjGrx2De2Y0ryNbbF6P-

\section{INFLUENCE OF LOGIC COURSES ON STUDENTS' BELIEFS AND INTUTITIONS}

Abstract: In this paper we survey and analyse the results from the project dedicated to the question - do logic courses influence students attitude concerning logic, and if they do, in which way? Our main prediction was that the logic courses do significantly influence relevant students' beliefs, and that influence (or the change) varies depending on the theoretical direction of the course in question. The method of our empirical inquiry was test-based examination of students' attitudes towards specific claims. We conduct the testing twice, before and after students have went through the relevant courses, and then compared the tests. Results, although different from hypothesis to hypothesis, do generally support the conclusion that logic courses influence relevant students' beliefs, and they typically do so in accordance to the theoretical direction of the given courses syllabuses.

Keywords: logic, argumentation, teaching, influence, change. 